\title{
kukasz Przybysz
}

Uniwersytet Warszawski

ORCID: 0000-0001-7227-1967

\section{Stygmatyzacja medialna public relations. Wyniki badania sposobów przedstawiania PR w polskich czasopismach opinii (2011-2016)}

\begin{abstract}
Streszczenie
W artykule poruszono problem stygmatyzacji public relations w polskich mediach z perspektywy przeprowadzonych badań ilościouych i jakościowych, dotyczących sposobów przedstawiania PR u czasopismach opinii. Z analizy wynika, że PR ma raczej negatywny wizerunek społeczny, na który upływa sposób, w jaki media używają tego terminu, kojarząc go z promocją, marketingiem, reklamą, wizerunkiem, propagandą itp. Negatywne użycie tego terminu wydaje się dość pouszechne, a charakterystyczną cechą polskiej sfery publicznej jest użycie wyrażenia „czarny PR” do dyskredytowania lub krytyki przeciuników. Zauważa się częste zastosowanie wyrażeń powiązanych z public relations w negatywnych konotacjach lub jako synonimów innych terminów. Powoduje to zmianę pierwotnego znaczenia PR na gorsze i prowadzi do postępującego niezrozumienia, a w konsekwencji wpływa na wizerunek, postrzeganie społeczne, rozwój i edukację public relations. Jest to sprzeczne z ideą public relations rozumianego jako strategiczny proces komunikacji, budujący i utrzymujący wzajemnie korzystne relacje. Podejście mediów i społeczeństwa źle wpływa na PR i prowadzi do eskalacji błędnego rozumienia public relations. Starając się znaleźć odpowiedzi i rozwiązania adekwatne do sytuacji obciążającej i wizerunku public relations u Polsce, nawiązaliśmy czterostronne partnerstwo między: 1) Wydziałem Dziennikarstua, Informacji i Bibliologii Uniwersytetu Warszauskiego, 2) Związkiem Firm Public Relations, 3) Instytutem Monitorowania Mediów 4) oraz polskim portalem branżouym Proto.pl. Wspólnie postanowiliśmy przeprowadzić badania u celu zarysowania głóunych obszarów zainteresowania i skali problemu. Starając się uzyskać najlepszą możliwą perspektywę i jakość materiałów, skupiliśmy się na polskich czasopismach opinii, które zgodnie z założeniem pouinny zawierać najbardziej zrównoważone i uznane treści. Przeprowadziliśmy analizę sześciu polskich czasopism z sześciu pełnych kolejnych lat wydawniczych (2011-2016), szukając wzmianek o PR. Analiza została podzielona na trzy poziomy: 1) wydźwięk, 2) słowa kluczowe, 3) rama znaczeniowa. Do agregacji danych wykorzystaliśmy dedykowaną bazę danych dostarczoną przez IMM, która wygenerowała ponad 780 unikalnych rekordów fraz związanych z PR. Zebraliśmy i podsumowaliśmy wyniki, aby lepiej zrozumieć, w jaki sposób public relations jest prezentowane w polskich mediach. Artykuł zawiera pogłębioną analizę zebranego materiału i jest kontynuacją opublikowanego wcześniej artykułu programowego.
\end{abstract}

Słowa kluczowe: public relations, PR, stygmatyzacja, czasopisma opinii, wizerunek. 


\title{
Media stigmatisation of public relations: research results of the depiction of PR in Polish opinion-forming magazines (2011-2016)
}

\begin{abstract}
The paper covers the issue of stigmatisation of public relations in Polish media from the perspective of quantitative and qualitative research on depiction of PR in opinion-forming magazines. We argue PR has a rather negative social image which we assume is affected by the ways the media use the term associating it with promotion, marketing, advertising, image, propaganda etc. A negative use of the term seems to be rather common. Moreover, it is characteristic for Polish public sphere to use the phrase dark PR to discredit or criticise the opponents. We observe a frequent use of phrases associated with public relations, where they appear in negative connotations or serve as synonyms for other related terms. This results in changing the primary meaning of PR for the worse and leading to its growing misunderstanding. We argue such a state of PR affects its image, social perception, its development and education. It is contradictory to the idea of public relations serving as strategic communication process building and maintaining mutually beneficial relationships. The approach of the media and society reflects badly upon PR and leads to an escalation of false information and idea of public relations. Trying to find answers and solutions adequate for the aggravating situation and image of public relations in Poland, we established a quadrilateral partnership between: 1) the Faculty of Journalism, Information and Book Studies, University of Warsaw, 2) The Polish Public Relations Consultancies Association, 3) The Institute of Media Monitoring, 4) a major Polish public relations professional portal Proto. pl. We collectively decided to conduct research to outline the main fields of concern and the scale of the problem. Trying to get the best possible perspective and quality material, we have focused on Polish political magazines which we assumed contained the most balanced and reputable content. We examined six Polish opinion-forming magazines and investigated six full consecutive publishing years (2011-2016) searching for any occurrence of phrases related to PR. The analysis has been divided into three levels: 1) connotation, 2) key words, 3) context frame. To aggregate the data, we used a dedicated database provided by the IMM which generated more than 780 unique records of phrases associated with PR. We gathered and summarized the findings to help understand the way public relations has been presented in Polish media. This paper contains an in-depth analysis of the collected material and is a continuation of the previously published program one.
\end{abstract}

Keywords: public relations, PR, stigmatisation, magazines.

\section{Wprowadzenie}

Artykuł jest kontynuacją opublikowanego pod koniec 2019 roku opracowania, w którym szczegółowo opisano założenia teoretyczne, będące podstawą do opracouania koncepcji i przeprowadzenia badań ${ }^{1}$. We uzmiankowanym artykule wyłożono dogłębnie problem negatywnego wizerunku i postrzegania public relations, pejoratywnego prezentowania dziedziny w mediach, co doprowadziło do opracowania koncepcji pojęcia stygmatyzacji

\footnotetext{
${ }^{1}$ Ł. Przybysz, Stygmatyzacja medialna public relations. Sposoby przedstawiania dziedziny $w$ polskich czasopismach opinii (2011-2016) - podstawy teoretyczne $i$ zarys badań, „Media Biznes Kultura" 2019, nr 2(7), s. 55-68.
} 
medialnej public relations ${ }^{2}$. Stygmatyzację medialną scharakteryzowano jako proces dyskredytacji obiektu w mediach i przez media. Konsekwencją takiego działania jest zmiana nastawienia społeczeństua do stygmatyzowanego podmiotu, co z czasem może skutkować koniecznością dystansowania się od niego, a nawet kompletnym odrzuceniem. Podkreślić należy, że efekty stygmatyzacji medialnej są truałe i niełatwo podlegają zmianom.

We uspomnianej publikacji omówiono ustępnie założenia przeprowadzonej analizy, by przybliżyć i unaocznić problem, który starano się następnie zgłębić w przeprowadzonych badaniach własnych. U ich podstaw legła hipoteza:

H1: Public relations podlega procesoui stygmatyzacji w polskich mediach.

Postawiono także konkretne pytania badaucze, które miały w założeniu doprowadzić do lepszego rozpoznania problemu zawartego w hipotezie:

Q1: Jaki jest wydźwięk wzmianek o public relations w badanych mediach?

Q2: Jakich słów kluczowych (terminów) związanych z public relations używa się w analizowanych publikacjach?

Q3: Z jakimi dziedzinami związanymi z komunikacją jest mylone lub błędnie utożsamiane public relations?

Q4: W jaki sposób przedstawiają public relations poszczególne czasopisma opinii poddane analizie?

W celu zweryfikowania hipotezy oraz udzielenia odpowiedzi na pytania badawcze przeprowadzono analizę zawartości kluczowych polskich czasopism społeczno-politycznych uznawanych za opiniotwórcze: „Neusweek Polska”, „Wprost”, „Polityka”, „Do Rzeczy”, „Sieci” i „Uważam Rze”. Jak opisano w artykule programowym4, badanie objęło okres sześciu pełnych lat wydawniczych: od 1 stycznia 2011 do 31 grudnia 2016. Wykorzystano do niego bazę monitoringu mediów (Biuletyn) Instytutu Monitorowania Mediów. Do analizy uybrano tygodniki „Neusweek Polska”, „Wprost”, „Polityka”, „Do Rzeczy”, „Sieci” i „Uważam Rze” ze względu na ich nakłady6, a także stopień opiniotwórczości według rankingu Instytutu Monitorowania Mediów oraz zróżnicowanie ideologiczne (od centrowych i wyważonych treściowo po zdeklarowane politycznie).

\footnotetext{
${ }^{2}$ Ibidem, s. 61-62.

3 „Do Rzeczy” był tygodnikiem do 2014 roku. Od tego momentu ukazuje się jako miesięcznik. Został poddany analizie, ponieważ przez część okresu podlegającego analizie ukazywał się jako tygodnik.

${ }_{4}^{4}$ Ł. Przybysz, Stygmatyzacja medialna public relations. Sposoby przedstawiania dziedziny..., op. cit., s. 55-68.

${ }_{5}$ Tygodnik ukazuje się od 2012 roku, zmiennie pod różnymi tytułami: „Sieci”, „W Sieci” i „Sieci Prawdy”. W tym opracowaniu będzie występować pod najbardziej ogólnym z nich: „Sieci”.

${ }^{6}$ Dane Związku Kontroli Dystrybucji Prasy, na podstawie: wirtualnemedia.pl, https://infogr.am/ acd2e827-ff40-495d-99b8-c782d93fb282 (dostęp: 20.03.2018).

${ }^{7}$ M.in. Najbardziej opiniotwórcze polskie media w 2015 roku, raport Instytutu Monitorowania Mediów, Warszawa, marzec 2016; Najbardziej opiniotwórcze polskie media w 2016 roku, raport Instytutu Monitorowania Mediów, Warszawa, luty 2017.
} 


\section{Analiza materiału}

Na ustępie do analizy zebranego materiału warto przypomnieć szczegóły przeprowadzonego badania. Próba badaucza objęła uszystkie uydania analizowanych czasopism od 1 stycznia 2011 roku do 31 grudnia 2016: było to w sumie 201 wydań „Do Rzeczy”, 312 „Newsweek Polska9”, 308 „Polityki”, 212 „Sieci”, 182 numery „Uważam Rze” oraz 309 wydań „Wprost”. Razem 1524 wydania. Z bazy danych wynika, że we uspomnianych numerach czasopism znalazło się 788 wzmianek dotyczących public relations. Przyglądając się dokładniej, można podać, że 186 spośród nich odnotowano we „Wprost” (24\%), 154 w „Newsweeku” (19\%), 144 w „Do Rzeczy” (18\%), 127 w „Uważam Rze” (16\%), 99 w „Polityce” (13\%) i 78 (10\%) w tygodniku „Sieci”10.

Idąc dalej, trzeba zauważyć, że najczęściej o public relations można było przeczytać w „Do Rzeczy”, ponieważ 81 spośród 201 wydań tygodnika zawierało wzmianki o PR (40\%). Wśród analizowanych czasopism opinii tym, które najrzadziej porusza kuestię public relations okazała się „Polityka”. Znaleziono tam 99 wzmianek o PR w 57 wydaniach spośród 308 z lat 2011-2016 (19\%) ${ }^{11}$.

Przeprowadzone badania pokazują zatem, że spośród 1524 wydań analizowanych czasopism społeczno-politycznych z lat 2011-2016 odniesienia do public relations zawierały 363 uydania, a zatem 24\%. Upraszczając nieco, można stwierdzić, że średnio w 1 na 4 uydania czasopism opinii można było znaleźć wzmiankę o PR, a najczęściej w tygodniku „Do Rzeczy” (u 2 na 5 wydań) ${ }^{12}$.

\section{Wydźwięk}

W pieruszej kolejności dokonano podziału i klasyfikacji treści ze uzględu na uydźuięk (por. rycina 1). Z zebranego materiału wynika, że badane tygodniki opinii wyrażają się o public relations najczęściej negatyunie (63\%). Z kolei 31\% wzmianek o PR ma charakter neutralny, a najmniej jest tych pozytywnych (6\%).

Analiza szczegółowa przynosi następujące unioski (por. rycina 2). Najczęściej o PR w kontekście negatyunym piszą kolejno: „Sieci” (83\%), „Newsueek” (70\%), „Polityka” (64\%) i „Uważam Rze” (62\%). Na dalszych miejscach znalazły się „Do Rzeczy” (55\%) i „Wprost” (53\%). Na przeciunnym biegunie znajdują się publikacje, w których tematyka public relations jest przywoływana u kontekście pozytywnym. Jest ich zdecydowanie mniej w stosunku do pozostałych: szczególnie u tygodniku „Sieci” (1\%), „Uważam Rze” (2\%) i „Newsweeku” (3\%). Można zaobserwować dysproporcję między wymienionymi tytułami a „Wprost” i „Do Rzeczy” (po 8\% pozytywnych wzmianek o PR) oraz „Polityką”

\footnotetext{
8 Tygodnik „Do Rzeczy” ukazuje się od 1.01.2013 roku.

${ }^{9}$ W dalszej części występuje jako „Newsweek”.

${ }^{10}$ Ł. Przybysz, Stygmatyzacja medialna public relations. Sposoby przedstawiania dziedziny..., op. cit., s. 64.

${ }_{11}$ Ibidem.

12 Ibidem, s. 65.
} 
z 16\% wzmianek o pozytywnym wydźwięku. W analizowanych czasopismach dość często można odnaleźć neutralne odwołania do tematyki public relations: najczęściej we „Wprost” (39\%), „Do Rzeczy” (37\%) i „Uważam Rze” (36\%). Nieco rzadziej tego rodzaju wzmianki można odnaleźć w „Newsweeku” (27\%) i „Polityce” (20\%), a najrzadziej w tygodniku „Sieci” (16\%).

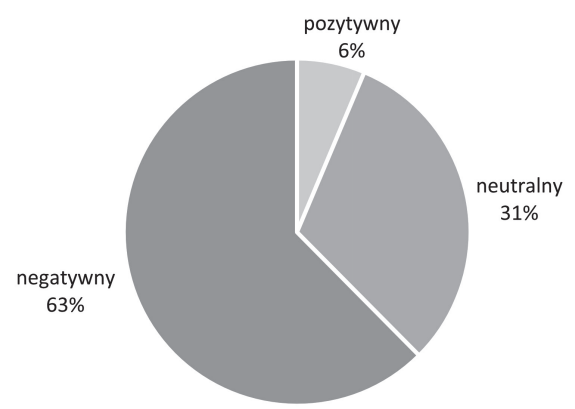

Rycina 1. Wydźwięk wzmianek o PR (w \%)

Źródło: opracowanie własne na podstawie danych IMM.

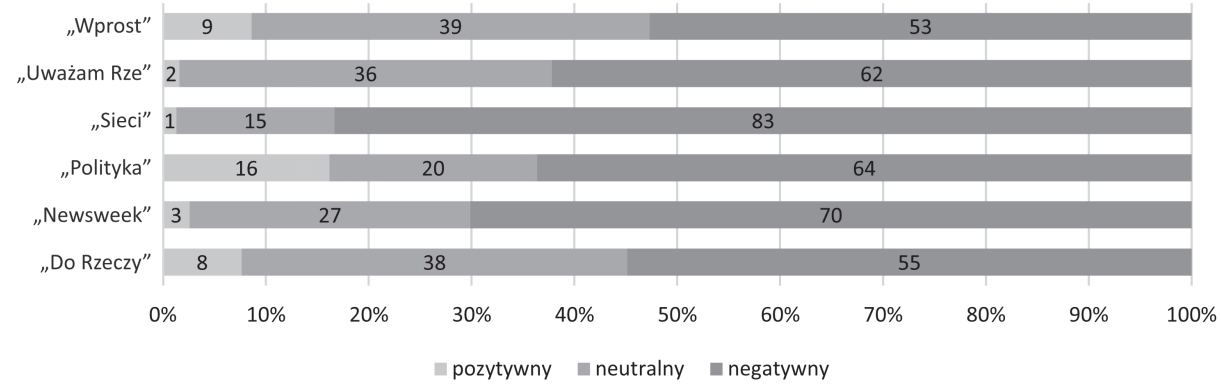

Rycina 2. Klasyfikacja wydźwięku wzmianek o PR (w \%) z podziałem na analizowane tytuły Źródło: opracowanie własne na podstawie danych IMM.

Warto zastanowić się $\mathrm{w}$ tym miejscu nad rozkładem czasowym wzmianek o public relations o charakterze pozytywnym, neutralnym oraz negatywnym (por. rycina 3). W latach 2012-2015 ogólna liczba wzmianek o charakterze negatyunym zamieszczonych $w$ analizowanych czasopismach sukcesywnie rosła. W 2011 roku liczba negatywnych wzmianek we wszystkich numerach czasopism wynosiła w sumie 55, w 2012 spadła do 38, by następnie wzrosnąć do 80 w 2013 roku i 124 w 2014. Najwyższą wartość osiągnęła w 2015 roku (137 wzmianek), by w 2016 spaść do 56. Trzeba podkreślić, że w 2014 roku, w którym pojawiło się najwięcej wzmianek o public relations o zabarwieniu pejoratywnym, najwięcej z nich zamieszczono w tygodniku „Do Rzeczy” (27). 


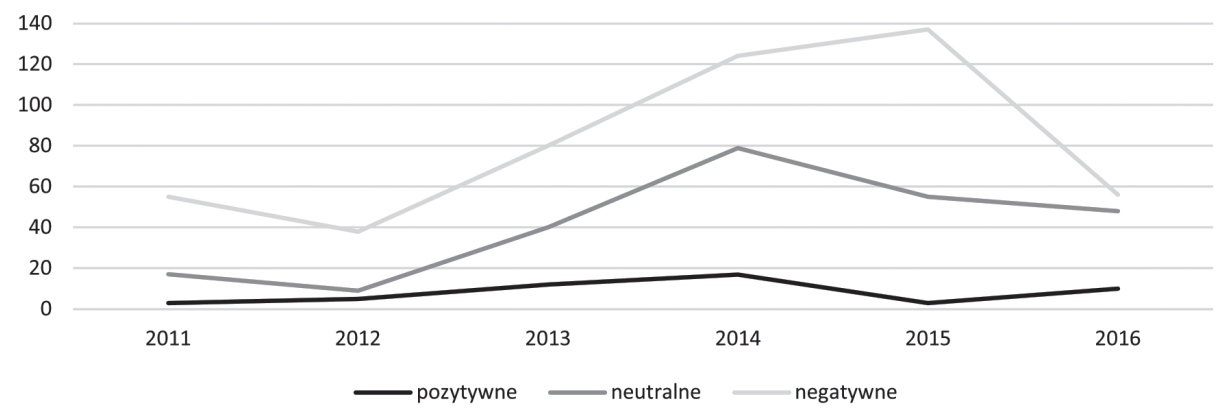

Rycina 3. Wydźwięk wzmianek o PR na osi czasu

Źródło: opracowanie własne na podstawie danych IMM.

Należy też spojrzeć na tę kuestię od strony liczby wydań, w których w danym roku najczęściej można było znaleźć negatywne wzmianki o PR. Na szczególną uwagę zasługuje fakt, że w 2014 roku wzmianki o PR zamieszczono w 17 wydaniach tygodnika „Sieci” i uszystkie traktowały o tej dziedzinie w kontekście pejoratywnym (w tym roku wydano w sumie 52 numery czasopisma). Pod tym względem tygodnik wyróżnia się na tle pozostałych poddanych badaniu, z których jedynie jeszcze w większości wydań „Uważam Rze” z 2014 roku poruszających tematykę PR, wzmianki o tej dziedzinie miały charakter negatyuny (u 8 na 10 wydań). Jeśli zaś wziąć pod uwagę ogólny odsetek wydań, w których wzmianki o PR miały charakter negatywny do całkowitej liczby wydań, w których tematyka public relations się pojawia, okaże się, że najwyższy wynik osiągają „Sieci” - 91\%. Dla poróunania, uskaźnik ten (stosunek liczby wydań ze wzmiankami o PR o charakterze negatywnym do liczby wydań zawierających jakiekolwiek wzmianki o dziedzinie) wynosi odpowiednio: 73\% w przypadku „Newsweeka”, 72\% w przypadku „Uważam Rze”, po 67\% dla „Do Rzeczy” i „Polityki” oraz 56\%, jeśli chodzi o „Wprost”.

Jeśli przyjrzeć się rozkładowi neutralnych wzmianek o public relations na osi czasu, można zauważyć, że również ich liczba rosła szczególnie w latach 2012-2014. Można zatem mówić o wzroście popularności tematyki public relations u tych latach. Najwięcej wzmianek o nastawieniu neutralnym odnotowano w 2014 roku (79), a spośród nich najwięcej pojawiło się w „Uważam Rze” (21), nieco mniej we „Wprost” (20) i „Do Rzeczy” (18). Biorąc zaś pod uwagę uszystkie wzmianki o PR znalezione w latach 2011-2016, najwięcej tych o nastawieniu neutralnym można odnaleźć we „Wprost” (72), a najmniej w tygodniku „Sieci” (12).

Na łamach analizowanych czasopism opinii najrzadziej można znaleźć wzmianki o charakterze pozytywnym. Podobnie jak tych o nastawieniu negatywnym i neutralnym, najwięcej ich odnotowano w 2014 roku (w sumie 17 we wszystkich tygodnikach). Najmniejszą liczbę wzmianek o PR o charakterze pozytyunym odnotowano w roku 2011 i 2015 (po 3). W tych latach czasopisma „Uważam Rze”, „Sieci”, „Polityka” i „Newsweek” nie opublikowały żadnej pozytywnej uzmianki o public relations, mimo że publikowały wtedy wzmianki o charakterze negatyunym (poza nieukazującym się w 2011 roku czasopismem „Sieci”). W sumie najwięcej pozytywnych wzmianek o public relations 
odnotowano we „Wprost” i „Polityce” (po 16), najmniej w tygodnikach „Sieci” (1) i „Uważam Rze” (2).

Ogólnie rzecz ujmując, we wszystkich omawianych czasopismach znaleziono 490 wzmianek negatywnych, 248 neutralnych i tylko 50 pozytywnych. Porównując to z liczbą wydań, w których znalazły się wzmianki o PR, można wskazać, że 69\% z nich (251 wydań) zawierało materiały o public relations o negatywnym wydźwięku. O ile więc o PR można przeczytać średnio w 1 na 4 uydania tygodników opinii, to aż w 2 na 3 z nich znalazły się publikacje ukazujące public relations w negatyunym świetle. Jeśli wziąć pod uwagę uzajemny stosunek do siebie wzmianek o PR o określonym zabarwieniu, okaże się, że na 8 wzmianek o dziedzinie 5 ma nastawienie negatyune, podczas gdy tylko 1 na 3 ma charakter neutralny. Dysproporcję widać jeszcze wyraźniej w przypadku porównania wzmianek o zabarwieniu pozytywnym do tych o pejoratywnym nastawieniu - na 9 negatywnych przypada tylko 1 pozytywna. Biorąc zatem pod uwagę omóuione tu dane, można uznać, że czytelnicy czasopism opinii otrzymują raczej negatyuny obraz dziedziny, mimo że publikacje o niej nie pojawiają się nader często na łamach analizowanych tytułów.

Na podstawie zebranych danych należy uskazać, że zaróuno najwięcej negatyunych treści, jak i najmniej pozytyunych można znaleźć u tygodniku „Sieci” (odnotowano tam tylko jedną wzmiankę o PR o nastawieniu pozytywnym). Tuż za nim znalazł się „Newsueek”. Natomiast „Wprost” stara się zachować równowagę u poruszaniu tematyki public relations: znaleziono w nim dużą liczbę wzmianek o PR w kontekście pozytywnym, które równoważy wiele neutralnych, przy jednoczesnym najmniejszym odsetku negatywnych wzmianek spośród wszystkich tytułów poddanych analizie.

\section{Słowa kluczowe}

W celu przeprowadzenia dokładniejszej analizy treści dokonano podziału zidentyfikowanych wzmianek na analizowane terminy (słowa kluczowe). Głównym kryterium były sformułowania użyte w publikacjach.

Wyznaczono sześć charakterystycznych wyrażeń kluczouych ${ }^{13}$ : „public relations”, „PR”, „PR-ouski”, „PR-owy”, „PR-owiec”, „,czarny PR”. Analizie poddano wszystkie ich formy i odmiany.

W zebranym materiale najczęściej występującym sformułowaniem jest „PR” (41\%). Znacznie rzadziej wykorzystywanym terminem jest „public relations” (18\%). Z taką samą częstotliwością pojawiają się odwołania do uważanego przez branżę za

${ }_{13}$ Wyznaczono następujące słowa kluczowe na podstawie ucześniejszych badań autora; por:: Ł. Przybysz, Stygmatyzacja medialna public relations. Analiza zjawiska w wybranych polskich czasopismach opinii, „Rocznik Bibliologiczno-Prasoznawczy” 2017, nr 9(20), s. 113-120; Ł. Przybysz, Dekadencja etyki polskiego public relations. Na przykładzie przetargu Kompanii Piwowarskiej [w:] Media Biznes Kultura. W kręgu starych i nowych mediów, red. M. Łosiewicz, A. Ryłko-Kurpieuska, TrueSign-Novae Res, Kinvara Co. Galway-Gdynia, Gdańsk 2016, s. 331-355; Ł. Przybysz, Czy jesteś dumny z bycia PR-owcem? Public relations w opinii studentów dziedziny, „Studia Medioznawcze” 2015, nr 2, s. 11-27. 
stygmatyzujące określenia „czarny PR” (18\%). Autorzy używają także terminu „PR-owiec” (we wszystkich odmianach), pisząc o działalności specjalistów public relations (14\%). Najrzadziej w badanych tytułach pojawiają się wyrażenia „PR-ouski” (6\%) i „PR-owy” (3\%) (por. rycina 4).

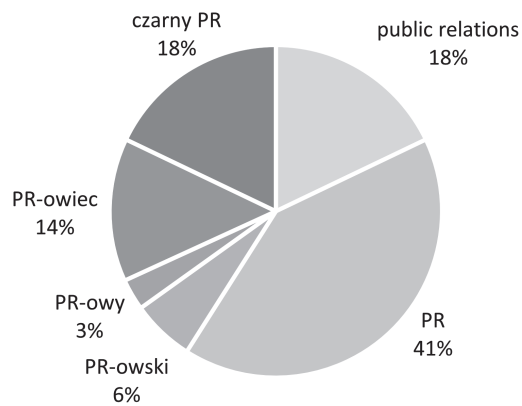

Rycina 4. Podział wzmianek o PR ze względu na użyte słowa kluczowe (w \%) Źródło: opracowanie własne na podstawie danych IMM.

Z badania częstotliwości występowania każdego z omawianych sformułowań w analizowanych tytułach nie wynika żaden wspólny model kategoryzacji treści o PR (użycia odpowiednich wyrażeń). W każdym z badanych tygodników rozkładają się one inaczej. Peune podobieństua można zauważyć pomiędzy „Newsueekiem” i „Wprost”, które w zbliżonych proporcjach używają każdej z kategorii, jednakże nie można mówić o analogii. Warto zaznaczyć, że uszystkie tytuły stosują najczęściej sformułowanie „PR”: odpowiednio pomiędzy 33\% („Sieci”) a 51\% („Polityka”) (por. rycina 5). Należy zatem spojrzeć na wyniki analizy pod kątem wykorzystania konkretnych kategorii. Pod tym względem sformułowania „public relations” najczęściej używa się w „Uważam Rze” i „Polityce” (odpouviednio: 27\% i 25\%), a najrzadziej we „Wprost” (11\%). Sformułowanie „PR-ouski” najczęściej pada u „Do Rzeczy” (10\%), najrzadziej zaś u „Neusweeku” (5\%); w „Polityce” nie pojawia się wcale. Określenie „PR-owy” najczęściej występuje we „Wprost” (6,5\% - podobnie jak poprzedni termin), a najrzadziej w „Newsweeku” (2\%). Nie pojawia się w publikacjach „Polityki” i „Sieci”.

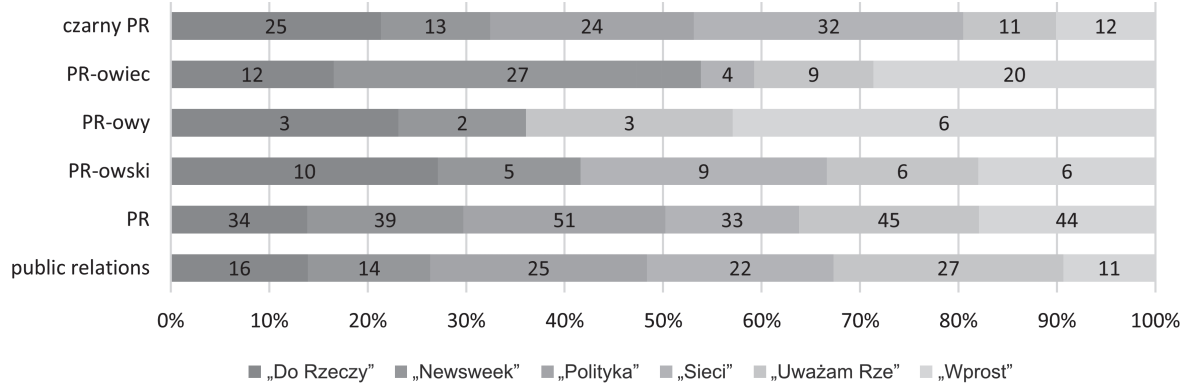

Rycina 5. Słowa kluczoue we wzmiankach o PR (w \%) z podziałem na czasopisma Źródło: opracowanie własne na podstawie danych IMM. 
O specjalistach public relations per „PR-owiec” najczęściej pisze „Neusweek” (27\%), a najrzadziej „Sieci” (4\%). Próżno szukać na wykresach dotyczących uspomnianych trzech sformułowań tygodnika „Polityka” - jak wykazała analiza bazy danych publikacji, w żadnym z uydań czasopisma nie można znaleźć zurotów „PR-ouski”, „PR-owy” czy „PR-ouiec”. Może to zatem tłumaczyć wysoki odsetek wcześniej opisanych słów kluczowych „public relations” i „PR” w publikacjach tygodnika - analiza szczegółowa wykazuje, że autorzy „Polityki” za pomocą tych określeń opisują działania public relations i specjalistów dziedziny. Należy także zurócić uwagę na fakt, że każde z czasopism odwołuje się do wyrażenia „czarny PR” (potocznie dotyczącego działań zmierzających do dyskredytacji, oczerniania, negatyunej zmiany postrzegania) $)^{14}$. Prym wiodą „Sieci” (32\%); za nimi znalazły się „Do Rzeczy” (25\%) i „Polityka” (24\%). Kolejne tytuły u znacznie mniejszym stopniu posługują się tym sformułowaniem: dla „Newsweeka” odsetek ten wynosi 13\%, dla „Wprost” 12\% i 11\% dla „Uważam Rze”.

W podsumowaniu należy zaznaczyć, że ogólnie rzecz ujmując najczęściej wykorzystywanym słowem kluczowym jest „PR”. Jego użycie odnotowano w 41\% wzmianek o public relations we wszystkich analizowanych czasopismach razem wziętych. Sformułowanie „PR” najczęściej można spotkać w „Polityce” (51\%), a najrzadziej w tygodniku „Sieci” (33\%). Na dalszych miejscach wśród najpopularniejszych wyrażeń dotyczących public relations znalazły się „,czarny PR" i „public relations” - oba po 18\%. Z punktu widzenia tej analizy szczególnie istotne jest to stygmatyzujące określenie - najczęściej o „czarnym PR-ze” pisano w tygodniku „Sieci” (32\%), a najrzadziej w „Uważam Rze” (11\%). W większości analizowanych czasopism pisano także o specjalistach public relations, używając wyrażenia „PR-owiec”. Najczęściej w „Newsweeku” (27\%), a najrzadziej w „Uważam Rze” (9\%) i u tygodniku „Sieci” (4\%). Spośród wzmianek w analizowanych czasopismach 6\% zawierało wyrażenie „PR-ouski” i najczęściej występowało w „Do Rzeczy” (10\%). Najrzadziej ze uszystkich słów kluczowych występuje sformułowanie „PR-ouy”, które odnotowano w 3\% wzmianek. Tym razem najczęściej we „Wprost” (6\%). Należy przypomnieć, że w „Polityce” nie odnotowano występowania słów kluczowych „PR-owiec”, „PR-owski” i „PR-owy”.

Można zatem uznać, że najpouszechniejszym sposobem odnoszenia się do dziedziny public relations nie jest posługiwanie się jej pełną nazwą, lecz skrótem „PR”. Przez to, zarówno dla czytelników, jak i dla autorów uypowiedzi, może on nie być w pełni zrozumiały. To z kolei może prowadzić do nader swobodnej interpretacji skrótu „PR” i nadawania mu znaczeń różnych od pierwotnego. Mogą się na to nakładać zarówno funkcjonowanie pochodzących z języka angielskiego form „public relations” i „PR”, jak i brak ich tłumaczenia na język polski oraz problem z pouszechnym uznaniem jednolitej definicji dziedziny. Nie sposób wyrokować, czy przeważają tu uzględy językowe, czy kognityune, jednakże uszystko to może u konsekwencji ugruntowywać niezrozumienie public relations przez publiczność.

14 J. Olędzki, Etyka w polskim public relations. Refleksje badawcze, Oficyna Wydawnicza ASPRA-JR, Warszawa 2009, s. 48-49. 


\section{Rama znaczeniowa}

Logiczną kontynuacją analizy było zaklasyfikowanie poszczególnych wzmianek i użytych słów kluczowych do zdefiniowanych na potrzeby badania siedmiu kontekstów znaczeniouych $^{15}$ (por. rycina 6). Wyszczególniono następujące konteksty: czarny PR/ dyskredytacja ${ }^{16}$, dziennikarstuo, manipulacja/propaganda ${ }^{17}$, marketing, public relations, rozgłos/promocja/reklama ${ }^{18}$, wizerunek.

W tym miejscu należy podkreślić, że wiele z analizowanych sformułowań odwołuje się do dziedzin pokrewnych, jak marketing czy dziennikarstuo, które mają zgoła inne zakresy działania i znaczenia od public relations, a są z nim błędnie utożsamiane. Warto odnotować, że część wzmianek prawidłowo odwołuje się do podstawowego kontekstu znaczeniowego PR-u, a więc public relations, a najczęściej pojawiają się one w odniesieniu do działań agencji, działów i ekspertów public relations.

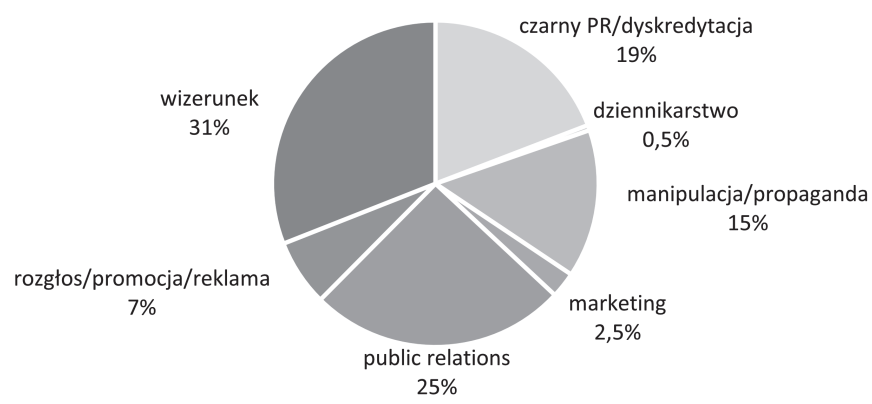

Rycina 6. Kontekst znaczeniouy wzmianek o PR (w \%)

Źródło: opracowanie własne na podstawie danych IMM.

Tylko 4 wzmianki odnosily się do PR w powiązaniu z dziennikarstuem: 3 w „Uważam Rze” i 1 w „Newsweeku”, co w sumie stanowi 0,5\% całości. Najczęstszy kontekst czyli „wizerunek” (31\%) - oznacza odnoszenie PR do kreowania wizerunku (niekiedy zastępując podstawowy zwrot na zasadzie synonimiczności). Prawidłowość ta dotyczy także pozostałych uyróżnionych sformułowań, co oznacza przypisywanie public relations znaczenia innego niż prawdziwe, zmianę zakresu znaczeniowego i narzucanie

\footnotetext{
${ }_{15}$ Wyróżnienie kontekstów oparto na własnym doświadczeniu badawczym i wielu publikacjach, m.in.: J. Olędzki, O wizerunku public relations $w$ polskim społeczeństwie, „Studia Medioznawcze” 2016, nr 1, s. 23-35; Ł. Przybysz, Stygmatyzacja public relations. Analiza zjawiska..., op. cit. i in.

${ }_{16}$ Czarny PR rozumiany jako dyskredytacja, działanie na szkodę przeciunika. Zob. Stownik pojęć zwiazanych z komunikacja marketingowa, red. Ł. Przybysz, https://www.prbezkomentarza.pl/ slowniczek/ (dostęp: 20.03.2018).

17 Zbiorczo, ponieważ ich rozróżnienie uprowadziłoby dodatkowe mikropodziały, co mogłoby negatyunie upłynąć na analizę szczegółową. Ponadto niekiedy bardzo trudno przypisać wzmiankę jednej tylko kategorii, znaczenia przenikają się, wynikają z kontekstu, co róunież skłania do uproszczenia analizy.

${ }^{18}$ Rozumiane jako działania prowadzące do budowania rozgłosu, promowania czegoś, uykorzystania PR do celów reklamouych itp.
} 
negatywnych konotacji poprzez nadmierną, nieuprawnioną interpretację. Jednakże trzeba zaznaczyć, że dość często spotyka się w omawianych czasopismach prawidłowy kontekst „public relations” - w przypadku 25\% wzmianek o dziedzinie.

Relatyunie często można spotkać też konteksty negatyune. Kontekst „czarny PR/ dyskredytacja” odnotowano w 19\% wzmianek o public relations. Warto przytoczyć przykłady. Tygodnik „Sieci” w jednej z publikacji pisze następująco: „Zorganizowana, gigantyczna akcja czarnego PR, demolowania wizerunku, niszczenia godności, przeprowadzona z niepraudopodobną brutalnością i skutecznością” ${ }^{19}$. W „Do Rzeczy” czytamy natomiast, że: „Geniusz czarnego PR polega właśnie na tym, że linczowany publicznie On nie może się bronić”20 oraz "Czarny PR ciągnie się za tą Bogu ducha winną rybą”21. W „Neusweeku” zaś przeczytamy: „czarny PR, czyli kompromitujące materiały na ich oponentów zdobyte poza telewizją"22.

Inny negatywny kontekst „manipulacja i propaganda” odnotowano w wypadku 15\% wzmianek o PR. Przykład z „Sieci”: „szóstka z public relations, kiedyś zuanej po prostu propagandą”23. W „Do Rzeczy” napisano o kimś, że „zausze mocno się bronił przed różnego rodzaju PR-ouskimi sztuczkami”24. „Newsweek” twierdzi, że „politycy mówią dziś o PR, nie o propagandzie"25.

Błędne postrzeganie public relations jako „rozgłosu, promocji i reklamy” odnaleźć można u 7\% wzmianek. Natomiast PR mylono z marketingiem u 2,5\% przypadków. Dla przykładu, „Do Rzeczy” łączy PR z marketingiem i zaleca: „Przy biurach prasouych diecezji [...] powinny poustać też biura PR i marketingu”26. Według „Uważam Rze” za działania public relations odpowiadają działy marketingu: „Akcje PR prowadzone we własnym zakresie przez działy marketingu w małych i średnich przedsiębiorstwach bywają bardzo pomysłowe"27.

Tytułami, w których najczęściej pisano o public relations w kontekście „wizerunku”, są "Newsueek” i „Wprost” (odpowiednio: 49\% i 31\%). Oznacza to, że niemal połowa publikacji o PR w tym pieruszym tytule spłyca jego znaczenie do narzędzia lub strategii stricte wizerunkowych. Po przeciunej stronie skali znajduje się „Polityka”, która w niewielkim stopniu utożsamia public relations z wizerunkiem (15\%). Dziennikarze i komentatorzy „Do Rzeczy” oraz „Polityki” najczęściej u sposób prawidłouy używają wyrażeń dotyczących PR w kontekście „public relations” (odpowiednio 35\% i 34\%); tymczasem w najmniejszym stopniu korzysta z tej interpretacji tygodnik „Sieci” (10\%). Inną różnicą jest zdecydowanie częstsze w porównaniu z pozostałymi tytułami przedstawianie PR-u przez „Wprost” w kontekście „manipulacji i propagandy” (24\%).

\footnotetext{
${ }_{19}$ Jak mainstream z prezydentem prawdzie pomagali, „Sieci”, 20.07.2015.

${ }^{20}$ Dziwne przypadki Kamila Durczoka, „Do Rzeczy”, 23.02.2015.

${ }^{21}$ Gdzie dorsze zimuja, „Do Rzeczy”, 15.02.2016.

${ }^{22}$ Męczennik kasa na żywo, „Newsweek”, 9.05.2016.

${ }^{23}$ Shreki, pity i masaże, "Sieci”, 10.11.2014.

${ }^{24}$ Fenomen Szydto, „Do Rzeczy”, 12.10.2015.

${ }_{25}$ Potrzebny jest wróg, „Neusueek”, 22.04.2014.

${ }^{26}$ Wtadza narracji, „Do Rzeczy”, 8.09.2014.

${ }^{27}$ Po co nam PR?, „Uważam Rze”, 1.09.2014.
} 
Najrzadziej u podobnym śuietle opisuje public relations „Newsweek” (3\%). PR jako „rozgłos, promocję, reklamę” najczęściej prezentuje „Uważam Rze” (17\%); najmniej tego rodzaju odniesień spotkać można w „Do Rzeczy” (1\%). W niewielkim stopniu public relations mylą z marketingiem cztery z omawianych tytułów: „Uważam Rze” (9\%), „Do Rzeczy” (4\%), „Polityka” (2\%) oraz „Sieci” (1\%). Brak takich odniesień w „Newsueeku” i „Wprost”.

Należy zaznaczyć, że w każdym z badanych czasopism występuje zbliżony odsetek wzmianek, w których utożsamia się public relations z „czarnym PR-em”. Najwięcej w tygodniku „Sieci” (37\%), dalej w „Polityce” (26\%), „Do Rzeczy” (20\%), „Wprost” (17\%) i „Newsweeku” (14\%). Najmniej podobnych odniesień kontekstouych występuje w „Uważam Rze” (12\%) (por. rycina 7). Można zatem uznać, że czytelnicy otrzymują zarówno dość negatywny obraz public relations, jak i mogą uznać, że działania prowadzące do dyskredytacji i szkalowania konkurentów należą do zakresu działań PR-owców. Może to prowadzić do sukcesyunego zmniejszania się zaufania do public relations, które i tak nie należy do najbardziej podziwianych zawodów ${ }^{28}$.

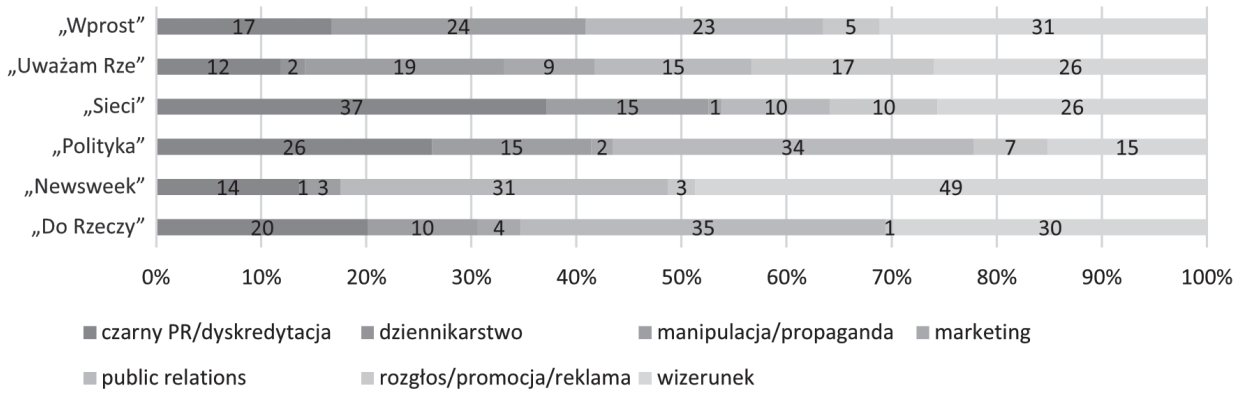

Rycina 7. Kontekst znaczeniowy wzmianek o PR (w \%) z podziałem na tytuły Źródło: opracowanie własne na podstawie danych IMM.

Podsumouując część analizy dotyczącą kontekstu znaczeniowego wzmianek o public relations, zuraca się uwagę, że dominuje utożsamianie public relations z wizerunkiem (31\%). Taka rama znaczeniowa występuje najczęściej w „Newsweeku” (49\%). Dalej warto zaznaczyć, że w wielu publikacjach PR przedstawiany jest we właściwym, niezniekształconym kontekście, jakim jest „public relations” (25\%). W tym wypadku przeważają uzmianki zamieszczone w „Do Rzeczy” (35\%) i „Polityce” (34\%). Trzecią pod uzględem popularności ramą znaczeniową jest „czarny PR/dyskredytacja”. Można uznać, że relatyunie wysoki odsetek wzmianek o takim charakterze (19\%) może przyczyniać się do niewłaściwego, a zarazem negatywnego postrzegania działań branży public relations. Rama znaczeniowa „czarny PR/dyskredytacja” występuje najczęściej w tygodniku „Sieci” (37\%). Inną ramą znaczeniową o wydźwięku pejoratywnym jest „manipulacja/

${ }^{28}$ J.E. Grunig, Instytucjonalizacja, zarzadzanie strategiczne i media elektroniczne: czy badania naukowe kształtują przyszłość public relations [w:] Public relations we wspótczesnym świecie: między stużba organizacji i społeczeństwu, red. J. Olędzki, Oficyna Wydawnicza ASPRA-JR, Warszawa 2011, s. 25. 
propaganda”. W tym kontekście o PR traktuje 15\% analizowanych wzmianek, a odniesienie to pojawia się najczęściej we „Wprost” (24\%). Kontekst „rozgłosu, reklamy i promocji” da się zaobserwować w wypadku 7\% wzmianek. Najczęściej pojawia się on w „Uważam Rze” (17\%), a najrzadziej w „Do Rzeczy” (1\%). Pozostałe konteksty znaczeniowe występują sporadycznie: „marketing” - 2,5\%, „dziennikarstwo” - 0,5\%.

Na podstawie pozyskanych danych można uznać, że PR jest rozumiany i przedstawiany głównie jako działanie wizerunkowe. Choć można znaleźć liczne uzmianki o właściwym kontekście znaczeniowym, wiele odnosi się do mniej pozytywnych ram znaczeniowych. Zatem róunież aspekt nadawania public relations określonego znaczenia może prowadzić do ugruntowania powierzchounego postrzegania dziedziny, a także przyczyniać się do postrzegania jej w negatywnym świetle.

\section{Wnioski}

Na podstawie przeprowadzonej analizy sformułowano następujące wnioski, które w skrócie zostały przedstawione w tabeli 1. Omawiane czasopisma opinii poruszają tematykę public relations średnio w 1 na 4 wydania z lat 2011-2016. Największą liczbę publikacji zawierających odniesienie do PR odnotowano we „Wprost”, a najmniejszą w czasopiśmie „Sieci”. Najuięcej wzmianek o public relations odnotowano w 2014 roku, co stanowi 28\% wszystkich znalezionych. Najmniej w 2012 roku - 7\% całości.

Tabela 1. Podsumowanie badania sposobów ukazywania PR u czasopismach opinii

\begin{tabular}{|l|l|}
\hline Czasopisma opinii o PR: & W 1 na 4 uydania \\
& Zdecydouanie negatyunie \\
& Najgorzej pisząą „Sieci” \\
\hline Najczęściej używają sformułowań: & „PR” \\
& „public relations” \\
& „,zarny PR” \\
\hline Wiążą PR z: & Wizerunkiem \\
& Public relations \\
& Czarnym PR (dyskredytacją) \\
\hline
\end{tabular}

Źródło: opracowanie ułasne.

Tygodniki opinii przedstawiają PR przeważnie w kontekście negatywnym, nieco rzadziej w neutralnym. Sporadycznie omawiają tematykę w znaczeniu pozytywnym. W 6 na 7 wydań odnotowano wzmianki o PR o zabarwieniu negatywnym: najwięcej w tygodniku „Sieci”, a najmniej we „Wprost”. Może to uskazywać na ogólny trend niezrozumienia i negatywnego postrzegania public relations przez media. Najwięcej pozytywnych wzmianek o PR wskazano w „Polityce” i „Wprost”, najmniej w czasopiśmie „Sieci” i „Uważam Rze”. Najwięcej negatywnych w „Newsweeku”, najmniej w „Polityce”. Najwięcej neutralnych odniesień znaleźć można we „Wprost”. Pozytywne odniesienia do PR pojawiały się najczęściej u 2014 roku, podobnie jak neutralne. Najwięcej negatyunych odnotowano w 2015 roku, a najmniej w 2012 roku. Tym 
samym u odpowiedzi na pytanie badawcze Q1 należy wskazać, że wydźwięk wzmianek o public relations odnalezionych w badanym materiale jest zdecydowanie negatywny.

Analiza słów kluczowych (która jest odpowiedzią na pytanie badawcze Q2) pokazuje, że najczęściej używanym sformułowaniem jest „PR”, które jest najpopularniejsze w „Polityce”. Kolejnymi popularnymi wyrażeniami są „public relations” i „czarny PR”. „Czarny PR” najczęściej pojawia się u tygodniku „Sieci”, a najrzadziej w „Uważam Rze”. Trzecim z kolei pod względem pouszechności słowem kluczouym jest „PR-owiec”. Najczęściej ze wszystkich tytułów stosuje go „Newsweek”. Zdecydowanie rzadziej posługują się nim „Uważam Rze” i „Sieci”. Nie używają go publicyści „Polityki”. Sporadycznie korzystano z terminu „PR-ouski”, najczęściej w „Do Rzeczy”. Jeszcze rzadziej sięgano po wyrażenie „PR-ouy”, najczęściej we „Wprost”. Żadne z tych określeń nie występuje w „Polityce”.

Odpowiadając natomiast na pytanie badawcze Q3 należy uskazać, że wśród wzmianek o public relations dominuje kontekst znaczeniowy „wizerunku”. Najczęściej pojawia się w „Newsweeku”. W części publikacji PR przedstawiany jest we właściuym kontekście „public relations”. Przeważają tu teksty „Do Rzeczy” i „Polityki”. Popularną ramą znaczeniową jest „czarny PR/dyskredytacja”, najczęściej występuje w „Sieciach”. Relatywnie wysoki odsetek wzmianek o takim charakterze może przyczyniać się do negatywnego postrzegania public relations. Innym kontekstem o negatywnym zabarwieniu jest „manipulacja/propaganda”. Odniesienie to pojawia się rzadziej od pozostałych, najczęściej w materiałach „Wprost”. Kontekst „rozgłosu, reklamy i promocji” da się zaobserwować okazjonalnie. Najczęściej pojawia się w „Uważam Rze”. Pozostałe konteksty znaczeniowe „marketing” i „dziennikarstwo” występują najrzadziej. Szczegółowe dane dotyczące sposobów przedstawiania public relations w każdym z czasopism opinii poddanych analizie stanowią odpowiedź na pytanie badawcze Q4.

\section{Podsumowanie}

Podsumourując, należy zaznaczyć, że przedstawiona analiza treści prezentuje w zarysie fenomen stygmatyzacji public relations w polskiej przestrzeni medialnej. Potwierdza hipotezę (H1), że public relations przedstawiane jest w negatywnym świetle i jest rozumiane jako „czarny PR”, dyskredytacja, manipulacja czy wręcz propaganda. Wyniki badania uskazują również na wyraźne problemy ze zrozumieniem zakresu zadań PR, ponieważ $w$ analizowanych publikacjach termin „public relations” funkcjonuje przede wszystkim w kontekście wizerunkowym.

Na podstawie zebranych danych, przedstawione tu wnioski można poszerzyć o szczegółowe interpretacje i odwołania - jak choćby wskazanie, w jakiego rodzaju materiałach redakcyjnych pojawiają się poszczególne wzmianki o PR, kto najczęściej wypowiada się o dziedzinie, kto najbardziej krytycznie itp. Badanie może także stanowić punkt uyjścia do analizy zjawiska w innych mediach: pozostałych rodzajach prasy, radiu i telewizji, a przede wszystkim internecie, ze szczególnym uwzględnieniem serwisów 
społecznościouych. Wyniki tak zakrojonego projektu badawczego mogą dostarczyć dalszych wniosków przydatnych przedstawicielom nauki i praktyki public relations, dziennikarzom oraz innym grupom społecznym.

Warto na koniec podkreślić, że członkowie koalicji wraz z autorem artykułu mają nadzieję, że prezentowany raport przyczyni się do zmiany podejścia mediów do public relations, a w konsekwencji jego społecznego postrzegania. O potrzebie prowadzenia badań, dyskusji i edukacji może świadczyć uskazana w raporcie pouszechna niepochlebna opinia o PR, podczas gdy jego kanonicznym zadaniem jest dbanie o reputację. Jak się okazuje, szczególnie własną.

\section{Bibliografia}

\section{Monografie}

Grunig J.E., Instytucjonalizacja, zarządzanie strategiczne i media elektroniczne: czy badania naukowe ksztattują przyszłość public relations [w:] Public relations we wspótczesnym świecie: między służbą organizacji i społeczeństwu, red. J. Olędzki, Oficyna Wydawnicza ASPRA-JR, Warszawa 2011.

Olędzki J., Etyka w polskim public relations. Refleksje badawcze, Oficyna Wydawnicza ASPRA-JR, Warszawa 2009.

Przybysz Ł., Dekadencja etyki polskiego public relations. Na przykładzie przetargu Kompanii Piwowarskiej [w:] Media Biznes Kultura. W kręgu starych i nowych mediów, red. M. Łosiewicz, A. Ryłko-Kurpieuska, TrueSign-Novae Res, Kinvara Co. Galway-Gdynia, 2016.

\section{Artykuły}

Olędzki J., Czarne sztuczki, propaganda i brudny PR. (Uzupetniony tekst referatu na III Kongresie PR w Wyższej Szkole Informatyki i Zarzadzania w Rzeszowie, kwiecień 2004).

Olędzki J., O wizerunku public relations w polskim społeczeństwie, „Studia Medioznawcze” 2016, nr 1, s. 23-35.

Przybysz Ł., Czy jesteś dumny z bycia PR-owcem? Public relations w opinii studentów dziedziny, „Studia Medioznawcze” 2015, nr 2, s. 11-27.

Przybysz Ł., Stygmatyzacja medialna public relations. Analiza zjawiska w wybranych polskich czasopismach opinii, „Rocznik Bibliologiczno-Prasoznawczy” 2017, nr 9(20), s. 113-120.

Przybysz Ł., Stygmatyzacja medialna public relations. Sposoby przedstawiania dziedziny w polskich czasopismach opinii (2011-2016) - podstawy teoretyczne i zarys badań, „Media Biznes Kultura” 2019, nr 2(7), s. 55-68.

\section{Źródła internetoue}

Dane Związku Kontroli Dystrybucji Prasy, na podstawie: wirtualnemedia.pl, https://infogr.am/ acd2e827-ff40-495d-99b8-c782d93fb282 (dostęp: 20.03.2018).

https://wuw.prsa.org/ (dostęp: 20.03.2018).

Instytut Monitorowania Mediów, https://www.imm.com.pl/ (dostęp: 20.03.2018).

PRoto.pl, http://wuw.proto.pl/ (dostęp: 20.03.2018).

Stownik pojęć zwiazanych z komunikacją marketingowa, red. Ł. Przybysz, https://www. prbezkomentarza.pl/slowniczek/ (dostęp: 20.03.2018). 
Łukasz Przybysz

Wydział Dziennikarstwa, Informacji i Bibliologii, Uniwersytet Warszauski, https://www.udib. uw.edu.pl/ (dostęp: 20.03.2018).

Związek Firm Public Relations, http://wuw.zfpr.pl/ (dostęp: 20.03.2018).

\section{Raporty z badań}

Najbardziej opiniotwórcze polskie media w 2011 roku, raport Instytutu Monitorowania Mediów, Warszawa, luty 2012.

Najbardziej opiniotwórcze polskie media w 2012 roku, raport Instytutu Monitorowania Mediów, Warszawa, luty 2013.

Najbardziej opiniotwórcze polskie media u 2013 roku, raport Instytutu Monitorowania Mediów, Warszawa, luty 2014.

Najbardziej opiniotwórcze polskie media w 2014 roku, raport Instytutu Monitorowania Mediów, Warszawa, luty 2015.

Najbardziej opiniotwórcze polskie media u 2015 roku, raport Instytutu Monitorowania Mediów, Warszawa, marzec 2016.

Najbardziej opiniotwórcze polskie media w 2016 roku, raport Instytutu Monitorowania Mediów, Warszawa, luty 2017. 